\title{
II
}

\section{"SOME REMARKS ON THE MORE REMOTE COMPLICATIONS OF GONORRHEA"}

\section{Discussion}

The President said he was sure all those present would feel greatly indebted to Dr. Gibson for this paper, so lucid and so far-reaching in its inquiry. It must have taken a good deal of preparation, and on such a hot afternoon it had been no light task to present it so ably. Hearing this paper made one feel that the manifestations of gonorrhœa might be almost as protean as those of syphilis, though he hoped they were not as frequent.

Before the discussion was commenced, he desired to propose that thanks be accorded to Dr. Gibson for his paper.

Colonel HARrison seconded, and it was agreed to.

Mr. S. H. Browning said he agreed with what Dr. Gibson said about gonorrhœal iritis. The first point in the paper which struck him was that concerning vaccines. One feature which had come out strongly in the treatment of gonorrhœal iritis was the absolute necessity for using vaccine treatment. He noted that Dr. Gibson said he worked up his vaccine dose to 300 millions ; but during the twenty years that the speaker had been looking after cases of gonorrhœal iritis at Moorfields it was found that small doses of vaccines were of but little value in these cases. There they never used detoxicated vaccines; he had found plenty of material for making his own vaccines. Ophthalmia neonatorum was now very seldom seen at Moorfields, and there were not many cases of acute gonorrhœa. He generally started with a dose of 250 million, as did his colleagues. The aim always was to produce a reaction; he always felt satisfaction if the reaction sufficed to alarm the house surgeon. In such an event, the course of the iritis could be looked forward to confidently as a short one, that the case would clear up with few, if any, synechiæ.

Another point was as to the period at which gonor265 


\section{BRITISH JOURNAL OF VENEREAL DISEASES}

rhœal iritis came on after the systemic disease. In 275 cases the average time of onset of the iritis was fourteen years after the last attack of gonorrhœa. His assistant, Dr. Biddle worked out the time in another I70 cases, and found that the average period was about nine years. The chief reason for the time difference was that Dr. Biddle came across three very rare happenings, namely, acute gonorrhœal iritis during the acute stage of the gonorrhœa. The speaker had never seen one case of the kind.

A further question which cropped up concerned the finding of gonococci after prostatic or vesicular massage in patients suffering from gonorrhœal iritis. In his first 275 cases gonococci were present in 9.7 per cent. of the cases, but since then the proportion has been. getting beautifully less; in the last series he looked up the percentage was 3 , this including the cases in which there was still acute urethritis. It was very rare indeed to see urethritis or any form of stricture in patients with gonorrhœal iritis.

Another matter of importance was, that one seldom saw gonorrhœal iritis in patients who had a clean mouth. When first he took charge of the V.D. Department at Moorfields there was a tendency to consider that all cases of iritis were gonorrhœal. Then a firm stand was made, and no case was accepted as gonorrhœeal until all other possible causes had been excluded. Until that had been done, no case was handed to the V.D. Department of that hospital. Dr. Biddle also pointed out in a paper that gonorrhœal iritis was very rare in people who had clean mouths; it was borne out in the speaker's private practice, as well as in hospital cases.

It was taught there-and those who knew Mr. William Lang's work would understand the value of it - that one could very often spot these cases of gonorrhœal iritisthe anterior chamber was full of greenish gelatinous exudate, and many of the cases he saw were already labelled before they arrived at his own room.

A further point was that, in his experience, acute iritis accompanied by a hyphæma was gonorrhœal in origin.

The question of metastasis was a very interesting one. $\mathrm{He}$ did not think gonorrhœal iritis was a metastatic condition; he felt convinced that it was purely a toxic condition. He agreed it was rather difficult to prove this, 


\section{REMOTE COMPLICATIONS OF GONORRHCA}

but he had never found, and, with the exception of one doubtful case, no one else had found the gonococcus in the eye in an acute gonorrhœal iritis or irido-cyclitis. $\mathrm{He}$ had, in many cases, drawn off the exudate from the anterior chamber and examined it direct, and by cultivation, but had never found anything even remotely resembling the gonococcus. In the doubtful case he referred to, that of Huguyens, a culture was done from the anterior chamber, and the investigator admitted pricking the iris and that the anterior chamber was filled with blood, which he drew off and cultivated, the patient at the time suffering from acute gonorrhœal septicæmia.

Dr. C. F. Searle (Cambridge) asked whether it was the general experience of members that the left lobe of the prostate was usually more involved than the right in cases of gonorrhœal disease. Had there occurred cases in which the prostate had been removed because of chronic prostatitis? One man he knew of had had six years of treatment, in clinics and privately, and yet had been having attacks of iritis for six or seven years. He was still suffering from chronic prostatitis. In such circumstances, was it justifiable to remove the prostate, seeing that obviously that organ was the source of the infection?

He wished to thank Dr. Gibson for his very instructive paper.

Dr. STOPFORD TAYLOR said he had been very interested in Dr. Gibson's paper, and he was reminded of one case while he was doing pathological work before the war; at the time it was not realised what was the cause of death. It was the case of a man who had injured his leg, and subsequently died of some cerebral trouble. At the autopsy an abscess was found in the brain, but on further examination an old chronic abscess the size of a walnut was found in the prostate. Seeing that it was found after death, cultures would not have been of much use, but there was no suppuration at the site of injury, and it was presumed there had been absorption of pus or toxins from the prostate.

Mr. Browning had referred to the treatment of iritis by vaccines. The speaker remembered one dramatic case, that of a boy who had developed acute gonorrhœal septicæmia three weeks after the primary infection, and then had joint troubles and iritis. Vaccines were tried, but the effect was nil. On the advice of a friend of 


\section{BRITISH JOURNAL OF VENEREAL DISEASES}

the speaker's he tried electrargol, and the rapidity of the clearing up after that was dramatic.

Another case of interest was that of a man who had had gonorrhœa a week, and was in the habit of taking large quantities of alcohol, and when seen he was on the verge of delirium tremens, therefore he, the speaker, wondered what he ought to do. He gave the man a half-dose of a well-known detoxicated vaccine, but within two days he developed gonorrhœal rheumatism. The vaccine was thereupon stopped, electrargol was given, and the condition settled down after five doses. A small dose of the same vaccine was tried again, and within forty-eight hours he developed epididymitis. $\mathrm{He}$ finally cleared up with further injections of electrargol.

Every now and then one came across a patient who apparently was doing well under treatment, and the urine became clear, so that one thought the end of treatment was arriving. Then one found that one lobe of the prostate was enlarging. Unless one, as it were, kept the finger on the prostate, one was apt to consider a case was cured when the patient still had an abscess locked up in the prostate. Cases ought to be submitted to not one but several examinations and massagings.

Dr. Hanschell said they all knew that Mr. Browning had had a very extensive experience of gonorrhœal iritis, and the speaker did not venture to criticise his statements, but it was noteworthy that Mr. Browning said the gonococcal vaccine dose must be large enough to bring on a reaction in the eye. His own experience was that not only must the dose be large enough to cause a definite local reaction, but also a definite paroxysm of fever. Therefore it apeared to him that in fact he had only given a sufficiently large amount of a foreign protein to cause " protein shock." He had abandoned gonococcus vaccine altogether, using instead typhoid vaccine, stock T.A.B. He used it intravenously, and in sufficient quantity to cause rigor and high access of fever. The eye quickly became alarmingly inflamed. Subsequent recovery was astonishingly quick. However, he had seldom seen the late results, for as soon as the eye was well his seaman patients left hospital, and he had not been able to ascertain whether relapses occurred.

With regard to the chronic inflamed prostate, due either to demonstrable gonococcus or to apparent post- 


\section{REMOTE COMPLICATIONS OF GONORRHEA}

gonococcus secondary infection, he had not found, in many cases, out-patient treatment by massage and irrigation of much use. But if the patient could be admitted to hospital and treated by "protein shock" (intravenous T.A.B. vaccine) as well as massage and irrigation, results were very good. He had treated a man eight years ago for acute gonorrhœa and prostatitis. After twelve weeks of massage and irrigation the patient left England. He had a gleet and an enlarged, slightly tender prostate; no gonococci could then be found. During the next five years he wrote from time to time complaining of occasional morning gleet and frequent lumbago, sciatica, rheumatism. A year ago the man came home, and a surgeon removed his still large and still tender prostate. The patient was then fortyeight years old. Since removal of prostate the patient declares himself to be perfectly well. This suggested that in some cases of chronic post-gonococcal prostatitis with " rheumatism," the prostate should be removed.

Mr. BRownING, in further remarks, said Colonel Harrison and he had frequently discussed whether a given condition was gonococcal or not. Part of his own duty was to give lectures to students at Moorfields, and he told them they must accept gonorrhœal iritis diagnoses with a certain amount of reserve. He also told them to use big doses, impressing on them the fact that one was then getting near to protein shock therapy.

The Chairman (Colonel Harrison) said he wished to join with others in congratulating Dr. Gibson on his admirable survey of this very complicated and difficult subject. Dr. Gibson mentioned a case of keratodermia in which fomentation brought out the lesions. That reminded the speaker of a case he saw the other day in his clinic, in which the man had had a Scott's dressing on the knee (keratodermia was associated with arthritis), and at the site where the dressing had been placed were nodules of keratodermia, and except for a few on the feet, they were the only lesions on the limbs.

He felt a good deal of scepticism as to the cases which Dr. Gibson described as gonococcal metastasis in the form of rare skin affections apart from keratodermia. When he read of these cases his feeling was that they had not been investigated properly from the bacteriological point of view ; so often it was reported that there were 
Gram-negative organisms indistinguishable from gonococci. That would not hold in a Court of Law, neither did the slide test hold there, and it did not carry weight with him, because there were certain streptococci which held the Gram stain rather feebly, particularly if they were well decolorised with methylated spirit. Such cases should be supported not only by carefully carried out Gram-staining and feeble counter-stain, but also by culture. Complement-fixation might support it. Numbers of these cases of chronic prostatic affection, giving off pus cells from the prostate, gave negative complementfixation, and on culture they showed streptococcus. He thought the latter and $B$. coli were responsible for more of these metastatic affections which were described as gonococcal than were the actual gonococcal ones. $\mathrm{He}$ felt a good deal of sympathy with Dr. Gibson's analogy of the chronic prostate with old fibrosis of the lung. $\mathrm{He}$ thought that every one who had to deal with prostates would agree that they were very difficult to keep straight. One kept them in order by massage, and he liked to supplement that by diathermy, which he regarded as a valuable aid, and it might act as a method of giving autogenous vaccine. Massage and diathermy was a better means than the former alone. One got them to a state in which repeated examination of slides showed no pus cells, and if one left them alone they relapsed. He felt much sympathy with the idea of dealing with them radically, but he had a fear that this remedy might be worse for the patient than the disease.

As to the complement-fixation test, he believed in supplementing the microscopical and cultural tests with that of complement-fixation; but there was one little fallacy, if he might so call it : one might get a positive complement-fixation reaction in sufferers from chronic catarrhalis infection, and it would be necessary in a case which gave a strongly positive complement-fixation reaction with gonococcal antigen to exclude a chronic infection with catarrhalis.

Dr. GiBson, in reply, thanked all who had discussed the paper. He brought it forward because he wanted to bring out the experience of members of the Society in regard to rare cases of complication in gonorrhœa, and in the discussion he thought his object had been achieved.

He was very grateful for Mr. Browning's account of 


\section{REMOTE COMPLICATIONS OF GONORRHEA}

iritis; he, the speaker, had felt that the gonococcal vaccine he used was of the nature of protein-shock therapy, but he pleaded guilty to believing that there might be, in some of these infections, a specific element, so it was better to suppose a gonorrhœal infection gave a gonorrhœal antigen than that it was an antigen from T.A.B. As to dosage, those who did not deal with eye diseases would not be likely to go so near the line in dosage in iritis cases as did eye specialists.

He had not noticed that the prostate was more affected on one lobe than the other.

Concerning Colonel Harrison's remarks, he agreed that one must be more sceptical than in the past as to what was and what was not a gonorrhœal infection, and he suggested that in future, instead of ordinary Gram's stain, Colonel Harrison should use Claudius' stain ; that was more fool-proof and easier, so that he could train the laboratory boy to do it quite reliably. The personal element was very considerable in carrying out the ordinary Gram's stain.

He would leave the question of metastasis, as it might lead to a stormy discussion!

Cases were then shown. 